Article

\title{
Building Local Institutional Capacities for Urban Flood Adaptation: Lessons from the Water as Leverage Program in Semarang, Indonesia
}

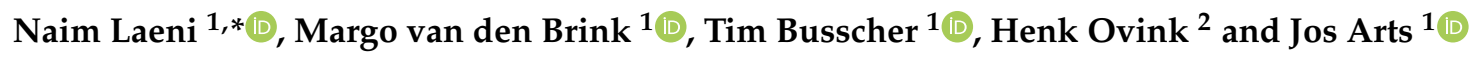 \\ 1 Department of Spatial Planning and Environment, Faculty of Spatial Sciences, University of Groningen, \\ Groningen, Landleven 1, 9747 AD Groningen, The Netherlands; m.a.van.den.brink@rug.nl (M.v.d.B.); \\ t.busscher@rug.nl (T.B.); jos.arts@rug.nl (J.A.) \\ 2 Special Envoy for International Water Affairs, Government of The Netherlands, Rijnstraat 8, \\ 2515 XP The Hague, The Netherlands; henk.ovink@minienw.nl \\ * Correspondence: n.laeni@rug.nl; Tel.: +31-50-3633896
}

Received: 22 October 2020; Accepted: 1 December 2020; Published: 3 December 2020

\begin{abstract}
Cities in Southeast Asia face various institutional barriers to cope with climate and water-related challenges. Several international programs for urban flood resilience therefore stress the importance of local institutional capacity building in initiating and delivering flood adaptation solutions. However, research to provide insights and recommendations into whether and how such international resilience programs could enable the building of local institutional capacities remains scarce. To bridge this gap, this paper presents an analytical framework to study institutional capacity building by international resilience programs, focusing on intellectual, social and political capital. The central case is the development and implementation of the Water as Leverage (WaL) program in Semarang, Indonesia. Our main results show that this program was able to stimulate the integration of knowledge, building of local coalitions and creation of adaptation narratives, which contributed to developing six strategic climate resilience proposals. This paper reflects on institutional strengths and weaknesses, and concludes that although the WaL program introduced an innovative approach for collaboration between international experts, urban designers and local stakeholders, sustaining momentum for the reflexive learning process, involving city-based NGOs and establishing formal links with decision makers were key challenges that hindered the development of institutional capacities to implement the developed proposals.
\end{abstract}

Keywords: resilience; flood resilience; flood adaptation; urban development; international program; institutional capacity; Semarang; Water as Leverage program

\section{Introduction}

Asian coastal cities are vulnerable to climatic and water-related risks, which are only exacerbated by on-going trends such as population growth, economic development, rapid urbanization and increased land use for agricultural production [1]. An important water challenge concerns increasing flood risks caused by climate-induced weather events, particularly extreme precipitation and rising sea levels [2]. This applies in particular to informal settlements and vulnerable communities since these are traditionally most exposed to social and economic impacts from flood events [3,4]. Despite the growing awareness that reducing flood risks requires careful planning for increasing resilience in current flood risk management strategies [5-10], their application in practice has proved to be notoriously difficult. For instance, a flood resilience approach calls for a systematic and inclusive process in which social and ecological vulnerabilities are acknowledged and opportunities to respond to an array of complex urban challenges are explored [6]. Such an approach could help cities to achieve Sustainable 
Development Goal 11 on inclusive, safe, resilient, and sustainable cities and human settlements [11]. However, currently many cities still heavily rely on a structural flood protection infrastructure, which has been criticized for its negative impacts on riverine ecosystems and its unreliability to mitigate climate change impacts $[7,12]$. Flood adaptation strategies, which allow cities to become more flexible for and responsive to extreme climate conditions, are either underdeveloped or experience great difficulties in the transition from planning to implementation $[6,13]$. In this context, an increasing amount of literature shows that the challenges of urban flood adaptation strategies are not only technical but are also particularly institutional in nature (see, e.g., [5,14]). As a consequence of a lack of "institutional feasibility" in existing legal, administrative, and financial frameworks, flood adaptation strategies are confronted with implementation barriers [5,15].

A flood resilience approach revolves around urban flood adaptation, including flexible measures and multi-functional designs, such as spatial reservations for water retention, flood-proof buildings, and water-sensitive neighborhoods [7,16-18]. However, in many countries, responsibilities to develop and implement flood risk management strategies are distributed among many different government organizations, which oftentimes strictly stay within the remit of their organization (see, e.g., [19,20]). Moreover, while stakeholder inclusion and open communication are important for building trust and a shared understanding of the issues, and also for ensuring the inclusion of the interests of the most vulnerable groups [21], such collaborative public engagement is often lacking in flood risk management processes. In the context of Southeast Asia, flood management institutions tend to concentrate on the promotion of large-scale flood protection infrastructure at the expense of local flood adaptation initiatives [20,22]. As a consequence, in order to allow the development and implementation of urban flood adaptation strategies, existing institutional capacities, particularly at the city level, need to be transformed.

International resilience programs in Southeast Asia are also paying increasingly more attention to the role of cities and their institutional capacity to initiate and deliver flood adaptation solutions for achieving sustainable and resilient urban development. For instance, the Asian Cities Climate Change Resilience Network (ACCCRN; 2008-2016) provided funding for flood adaptation micro-interventions (such as pilot projects) and the establishment of a knowledge network to support local government agencies and academics in "mainstreaming" resilience policy and climate adaptation programs [23]. As another example, the 100 Resilient Cities (100RC) program (2013-2019) funded a chief resilience officer for each city member and assisted the city governments to formulate and implement a comprehensive and city-wide resilience strategy [10]. A more recent program, the Water as Leverage (WaL) Program for Resilient Cities Asia (2018-present), promotes the development of local institutional capacities to co-create urban flood adaptation solutions in the vulnerable Asian coastal cities of Chennai in India, Khulna in Bangladesh, and Semarang in Indonesia [24]. While previous studies have mainly focused on the assessment of the outcome of these international resilience programs, i.e., the ability of such programs to operationalize, and institutionalize resilience policy changes in the national and local planning institutional contexts [23,25-27], research providing insight into whether and how these programs have succeeded in building local institutional capacities remains scarce.

This paper aims to bridge this gap by exploring whether and how international resilience programs enable the building of local institutional capacities for the development and implementation of flood adaptation strategies in Southeast Asian cities. As proposed by Cars et al. [28] and Healey [29,30], the building of institutional capacity for transformative impacts in local contexts requires the development of intellectual, social, and political capital. These three elements of institutional capital also structure our analytical framework, which integrates insights from flood resilience literature (e.g., [5-7,9,13,16,31]) and institutional capacity building literature (e.g., [28,29,32-35]). By means of this framework, we can analyze whether and how programs succeed in developing local institutional capacity for urban flood adaptation. We focus on the WaL program in Semarang, Indonesia. Semarang has strong experience in international collaboration for urban resilience. The city was not only selected as one of the pilot cities of the WaL program but was also previously part of both the ACCCRN and the 100RC program. 
The remainder of this paper is structured as follows. Section 2 elaborates on our analytical framework and explains the three institutional capitals required for analyzing local institutional capacity building for urban flood adaptation. The research methodology and case study are explained in Section 3. Section 4 presents an empirical analysis of the process design and outlines the key activities that have thus far been part of the WaL program in Semarang. Section 5 discusses the key findings by reflecting on the institutional challenges and weaknesses that the WaL program, and also other international resilience programs in Southeast Asia and other developing countries, encounter in local institutional capacity building for urban flood adaptation. This paper ends with conclusions and recommendations for international resilience programs aiming to create sustainable local impacts in climate and coastal vulnerable cities and regions.

\section{Local Institutional Capacity Building: International Resilience Programs for Urban Flood Adaptation}

Developing and implementing urban flood adaptation strategies requires local institutional capacities that enable the exploration of innovative ideas, collaboration and experimentation with new approaches, and the transformation of existing policy practices $[5,7,9,16,33]$. Urban flood adaptation strategies can incorporate new ways to stimulate inclusive stakeholder engagement and the integration of flood adaptation solutions in spatial planning and urban design $[6,9,13,34]$. Currently, many Southeast Asian cities lack the institutional capacity to engage in urban flood adaptation. In general, institutional capacity is referred to as the capacity of urban governance to increase the qualities of places [28]. This capacity is reflected in collective resources, the mobilization of actions from social relations, and the interaction between local stakeholders within government, private, and voluntary sectors [29]. According to various planning scholars [26,27,29,32], "institutional capital" is a conceptual device that is used to link three key elements in social interaction and place-making, namely intellectual capital, social capital, and political capital. As explained by Cars et al. [28], "building 'institutional capacity' requires transforming, creating, and mobilizing 'institutional capitals' of a place in the collective effort of shaping its future" [28].

To study how international resilience programs-in their process designs and program activities - enable the building of local institutional capacities, we continue on the distinction between intellectual, social, and political capital. Intellectual capital refers to the ability to draw insights and expertise from a wide range of knowledge resources and to organize the learning processes needed for understanding and exploring policy contexts and solutions [35]. Social capital refers to the ability to organize inclusive and collaborative processes to create mutual trust and build relational networks between a wide range of actors [36]. Political capital reflects the ability to mobilize resources and build shared consensus and perspectives for achieving policy outcomes [30]. Based on insights from flood resilience literature $[5-7,9,13,14,34]$, we converted these three capitals into an analytical framework for examining the institutional capacity building efforts by international resilience programs, as presented in Table 1.

Table 1. An analytical framework for analyzing local institutional capacity building by international resilience programs.

\begin{tabular}{|c|c|c|c|}
\hline Elements & Attributes & Activities & Key References \\
\hline \multirow{7}{*}{$\begin{array}{l}\text { Intellectual } \\
\text { capital }\end{array}$} & Knowledge integration & $\begin{array}{l}\text { Combining various fields of expertise, such as spatial design } \\
\text { and planning, disaster and emergency management, } \\
\text { engineering, hydrology, and ecology }\end{array}$ & $\begin{array}{l}\text { Restemeyer et al. [13]; } \\
\text { Driessen et al. [14]; } \\
\text { Bergsma [37] }\end{array}$ \\
\hline & Local knowledge & $\begin{array}{l}\text { Using insights, experiences, and perspectives of local actors, } \\
\text { especially regarding social and physical vulnerabilities }\end{array}$ & $\begin{array}{l}\text { Pelling and High [38]; } \\
\text { Bergsma [37] }\end{array}$ \\
\hline & & Improving policy implementation and monitoring processes & Gupta et al. [39]; \\
\hline & Single-loop learning & to realize existing policy goals and strategies & Pahl-Wostl et al. [15] \\
\hline & & Reflecting on and adjusting existing policy goals & Pahl-Wostl et al. [15]; \\
\hline & Double-loop learning & and strategies, allowing exploration and experimentation with & Folke et al. [40]; \\
\hline & & innovative approaches and new ideas & Gersonius et al. [5] \\
\hline
\end{tabular}


Table 1. Cont.

\begin{tabular}{|c|c|c|c|}
\hline Elements & Attributes & Activities & Key References \\
\hline \multirow{3}{*}{$\begin{array}{l}\text { Social } \\
\text { capital }\end{array}$} & Inclusiveness & $\begin{array}{l}\text { Stimulating collaborative processes between diverse } \\
\text { stakeholders at different levels and supporting close } \\
\text { engagement with communities }\end{array}$ & $\begin{array}{l}\text { Wesselink et al. [12]; } \\
\text { Restemeyer et al. [13]; } \\
\text { Gersonius et al. [5] }\end{array}$ \\
\hline & Shared values & $\begin{array}{l}\text { Creating shared values on holistic and social dimensions in } \\
\text { the design of flood adaptation solutions }\end{array}$ & $\begin{array}{l}\text { Cars et al. [28]; } \\
\text { Liao [7]; } \\
\text { Lebel et al. [4]; } \\
\text { Pelling and High [38] }\end{array}$ \\
\hline & Network integration & $\begin{array}{l}\text { Integrating wider climate resilience and flood risk } \\
\text { management networks }\end{array}$ & $\begin{array}{l}\text { Cars et al. [28]; } \\
\text { Pahl-Wostl [41]; } \\
\text { Khakee [35] }\end{array}$ \\
\hline \multirow{5}{*}{$\begin{array}{l}\text { Political } \\
\text { capital }\end{array}$} & Local ownership & $\begin{array}{l}\text { Supporting dialog and shared responsibilities by local actors } \\
\text { to adopt and develop flood adaptation solutions }\end{array}$ & $\begin{array}{l}\text { Booher and Innes [32]; } \\
\text { Bergsma [37] }\end{array}$ \\
\hline & Resources mobilization & $\begin{array}{l}\text { Drawing essential financial and human resources, } \\
\text { and technical capacities, to develop and implement flood } \\
\text { adaptation solutions }\end{array}$ & $\begin{array}{l}\text { Healey [29]; } \\
\text { Cars et al. [28]; } \\
\text { Khakee [35]; } \\
\text { Restemeyer et al. [13] }\end{array}$ \\
\hline & Policy alignment & $\begin{array}{l}\text { Embedding flood adaptation solutions in formal } \\
\text { administrative and decision-making processes }\end{array}$ & $\begin{array}{l}\text { Breukers } \\
\text { and Wolsink [42]; } \\
\text { Wesselink et al. [12] }\end{array}$ \\
\hline & Building a narrative & $\begin{array}{l}\text { Create aspiring agendas to attract funding and influence } \\
\text { decision making for transforming flood adaptation practices }\end{array}$ & $\begin{array}{l}\text { Davoudi et al. [43]; } \\
\text { Restemeyer et al. [17] } \\
\text { Healey [29]; }\end{array}$ \\
\hline & Change-agents & $\begin{array}{l}\text { Stimulating leadership roles of front-runners, initiators, } \\
\text { and local champions to influence and sustain policy efforts }\end{array}$ & $\begin{array}{l}\text { Khakee [35]; } \\
\text { Restemeyer et al. [13]; } \\
\text { Meijerink et al. [44] }\end{array}$ \\
\hline
\end{tabular}

\subsection{Intellectual Capital}

Knowledge resources and learning are crucial to form an adequate problem definition and to develop suitable policy solutions. The following four key attributes are important in the build-up of knowledge resources and the organization of learning in international resilience programs (cf. $[7,13,15,36])$. Firstly, the program needs to integrate knowledge from various fields of expertise, such as engineering, spatial design and planning, disaster and emergency management, and environmental ecology [13,14]. Bergsma [37], for example, asserts that spatial planning knowledge is essential for reducing flood risks by defining "what measures are available to local actors to make flood-resilient location choices or to flood-proof their buildings, [and what costs are involved] with taking such measures". In this context, Pahl-Wostl et al. [15] highlight the informal space that is needed to support the integration of knowledge and experimentation with flood adaptation initiatives. The program could organize "soft spaces", such as in the form of technical consultation, an examination by an independent panel, and a joint working group with policy makers from multiple agencies from regional, national, and international levels, to integrate a wide range of knowledge resources and expertise in the development of flood adaptation strategies [45]. Secondly, it is also important that international resilience programs incorporate local knowledge and insights from local communities and stakeholders regarding the local context and culture. This leads to an in-depth understanding of social vulnerabilities that are derived from environmental and climate challenges [37,38]. In addition, by integrating local insights and knowledge into the process design of the program and in its activities, it is possible to formulate and co-create flood adaptation solutions.

Thirdly, international resilience programs should enable cities to reflect on and improve existing flood risk management through single-loop learning. Single-loop learning refers to a learning process that aims at the incremental improvement of existing goals and strategies [15]. The learning process could, for instance, focus on enhancing or building on existing flood adaptation initiatives, such as providing local communities with more resources for flood preparedness or scaling up rain harvesting projects in communities. Fourthly and finally, intellectual capital for urban flood adaptation also requires double-loop learning, which, in the context of international resilience programs, refers to the organization of a more critical and reflexive learning process aimed at the existing problem framing, the strategic goals, and the policy formulation process. Double-loop learning, therefore, entails the continuous exploration of innovative approaches that have resulted in the development and experimentation of 
new measures [15,41]. As explained by Restemeyer et al. [13], flood adaptation requires a mindset among policy makers and stakeholders that not only emphasizes urban flood safety but also includes added values, such as spatial quality and the natural environment. For long-term flood adaptation, after the program has ended, the city itself should be able to initiate and organize the learning process for building intellectual capital.

\subsection{Social Capital}

Social capital involves forging and maintaining social relations and interactions between a wide range of actors. This will build relational resources that enable coalition building and the development of shared values for influencing decision-making in the policy process [38]. Firstly, in building social capital for flood adaptation, inclusiveness is necessary regarding the collaboration between various stakeholders, both individuals and institutions within government, private, NGO, academic, finance, and other sectors in society, as this creates network power from diverse participants [32]. Diverse participation and open communication in international resilience programs can create trust and a shared understanding of promoting local collective actions to reduce flood risks [21]. Secondly, international resilience programs could encourage the development of shared values among policy makers and stakeholders to promote an inclusive flood adaptation approach, which aims to reduce vulnerabilities to floods among disadvantaged communities, particularly in the context of developing counties. The consideration of social vulnerabilities and the adoption of a holistic perspective, which takes into account social, ecological, and economic dimensions of urban and water systems, are important for coalition-building toward and policy change for flood adaptation [9,13,21]. Thirdly, building social capital requires network integration to connect various policy networks and social groups (e.g., connecting local-based networks to international organizations) in order to increase mutual understanding and strengthen collaboration to tackle the issue of flood adaptation [28,41]. International resilience programs could stimulate and improve the connection between networks established at the city level within the program with other and wider networks at regional, national, and international levels. The establishment of new and improved connections relates to the mobilization of resources, which we discuss in more depth in the following sub-section on political capital.

\subsection{Political Capital}

Political capital reflects the ability to obtain essential public and private resources and to formalize the developed flood adaptation strategies in legal, administrative, and policy frameworks [13]. Several studies have identified different attributes of political capital for developing and implementing new policy initiatives $[29,32,40]$. The generation of political capital for urban flood adaptation firstly requires local ownership of flood adaptation ideas, solutions, and measures. Wesselink et al. [12], for instance, argues that adaptation strategies should be developed together with regional and municipal planning authorities. Moreover, local willingness, interests and responsibility are essential for policy change. It is therefore important that international resilience programs stimulate local ownership of the process and the developed solutions. Secondly, the mobilization of resources, such as funding, human resources, and technical capacities, is essential in international resilience programs. This aspect also includes the ability to draw political support for local initiatives [35]. In this context, sharing resources and responsibilities among public and private actors in reducing flood risks is becoming increasingly relevant [13]. International resilience programs could facilitate and coordinate resource mobilization for the city government and local NGOs, for instance, access funding for strategy development and implementation. Thirdly, policy alignment is important to ensure the swift implementation of the developed flood adaptation solutions by embedding them in the formal policy process at the local, regional, and national governance levels [42]. The aim of international resilience programs then is to deliberately influence decision making at the political level to support flood adaptation initiatives to, for example, integrate flood adaptation in a wider planning system such as local land-use planning, transportation systems, and blue-green infrastructure development $[9,12]$. 
Fourthly, it is essential that international resilience programs build a narrative of adaptation, that is, build a political story of inspiration and aspiration that can connect, put on the agenda, activate, attract funding, convince decision makers, and strengthen collaboration across sectors and levels [43]. For example, according to Restemeyer et al. [17], a resilience narrative can transform flood risk management practices, and create an agenda that can drive change, stimulate the exploration of new pathways, set an agenda, and test the unknown. As a result, the created narrative could formalize the informal, and turn ambitious adaptation strategies to policy implementation. Fifthly and finally, the engagement of local change-agents, such as resilience front-runners, epistemic communities (experts and universities), and local champions, is important for stimulating and influencing policy change and sustaining long-term resilience policy efforts $[15,28]$. By empowering these local change-agents, international resilience programs could enhance the overall local institutional capacities by facilitating the exploration of innovative policy processes and solutions for flood adaptation [21,44].

\section{Research Methods}

\subsection{Case Study: Water as Leverage for Resilient Cities Asia in Semarang}

We used the Water as Leverage (WaL) for Resilient Cities Asia program in Semarang, Indonesia, as a central case study for analyzing local institutional capacity building for urban flood adaptation. Building on the experience of the Rebuild by Design (RBD) program that was set up after Hurricane Sandy hit New York and New Jersey [46,47], the WaL program introduced a resilience by design approach in the context of developing countries in Southeast Asia. Resilience by design was modeled as: "an opportunity to innovate and develop more creative solutions and integrated strategies that could build resilience, sustainability and livability into solutions" [46]. The former principal of rebuild by design, who is currently the Special Envoy for International Water Affairs for The Netherlands, initiated the Water as Leverage program in collaboration with the 100 Resilient Cities program created by the Rockefeller's Foundation, the Asian Infrastructure Investment Bank, UN-Habitat, and various international partners (International Architecture Biennale Rotterdam, Architecture Workroom Brussels, the Global Centre on Adaptation, the Dutch Environmental Assessment Agency, Deltares, Fabrications, the OECD, WWF, FMO, the World Bank Group, the Islamic Development Bank, the Green Climate Fund, the Asian Development Bank, and the German Development Bank (KFW). The WaL program is the first experiment and application of a "resilience by design" approach in other countries, especially in developing countries.

The development and implementation of the WaL program was funded by the Dutch government, i.e., the Ministry of Foreign Affairs, and was executed by The Netherlands Enterprise \& Development Agency (RVO). The Water as Leverage program in Semarang had four main goals to address flood and climate risks in Asian cities [48]. The first was to identify and develop holistic and integrated climate solutions with the opportunity to scale-up and replicate these solutions (for an overview of the developed climate resilience proposals in Semarang see Figure 1). The second goal was to build stakeholder coalitions for the co-creation of climate solutions (see Figure 2). The third main goal was to introduce and broker innovative financial arrangements together with financial and governmental partners, and thereby institutionalize the developed climate solutions in practice. Finally, the fourth goal was to use these first projects as opportunities to replicate and scale-up to catalyze sustainable development and climate action across Asia and the world [22,47,48]. It should be noted that one of the co-authors of this paper is also the initiator of the program and the Special Envoy for International Water Affairs for The Netherlands. His contribution was twofold: he firstly provided access to data in the shape of program workshops, initial sets of interviews, and program documents, and, secondly, after the data collection and analysis were completed, he reflected and validated the findings based on his personal experience in the program. 


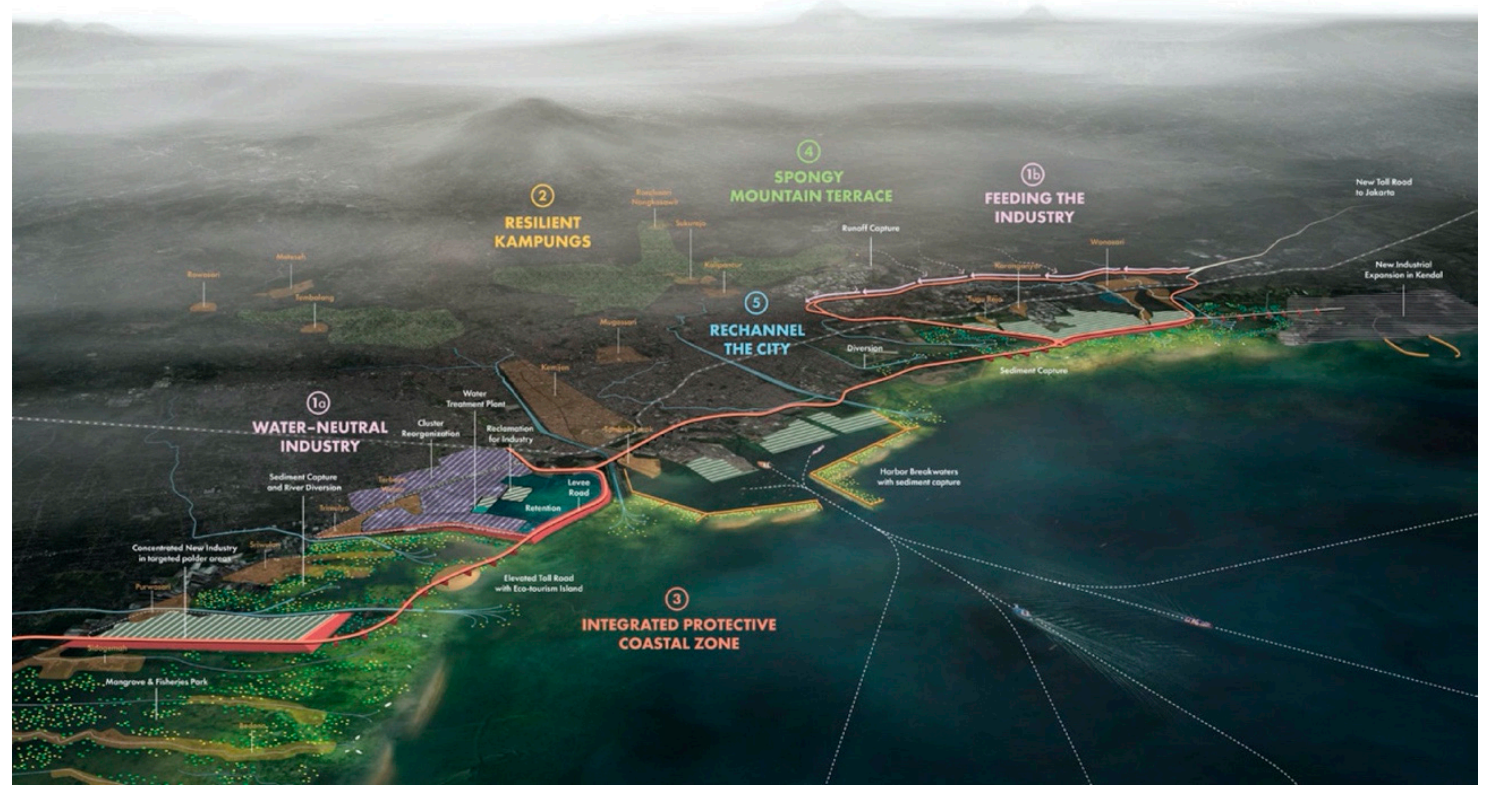

Figure 1. Conceptual design of the climate resilience proposals developed in the Water as Leverage program in Semarang (Source: Water as Leverage 2019-image produced by the two design teams One Resilient Semarang and Cascading Semarang).

\section{THE WATER AS LEVERAGE APPROACH}

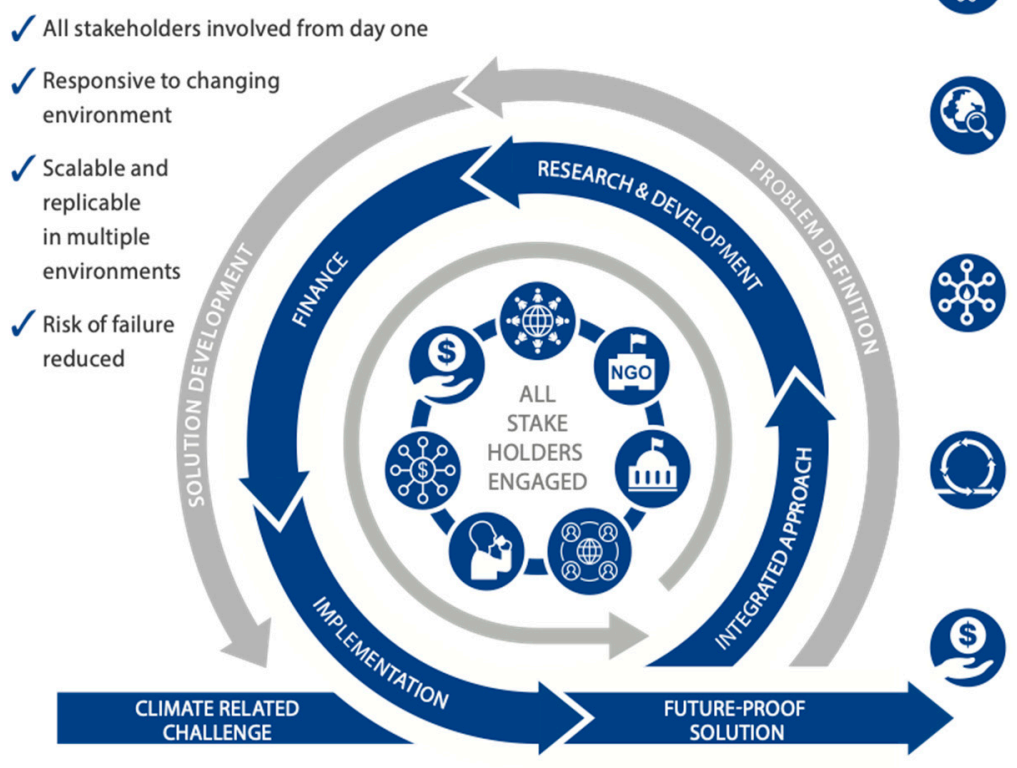

People

Combine the world's best expertise with local talent.

$R \& D$

Catalyze innovative processes to understand vulnerabilities to future risks and uncertainties.

Integration

Co-ordinate closely with local communities and governments in an agile working environment.

Process

Ensure Government and community stakeholders work closely with experts from day one.

Finance

Source innovative project funding through public private partnerships, blended and private finance initiatives.

Water as Leverage is an initiative of the Government of the Netherlands

Water as Leverage $\odot 2019$ www.waterasleverage.org

Figure 2. The Water as Leverage method (Source: Dutch Special Envoy for International Water Affairs 2019).

\subsection{Data Collection and Analysis}

This paper is based on qualitative data obtained from participatory observations, semi-structured interviews, and the analysis of policy documents and reports. The fieldwork in Semarang was conducted during March and April of 2019. During the fieldwork, several meetings, workshops, and field visits were attended and arranged (see Appendix A Table A2). These included field visits to potential program pilot sites, three meetings with academics and experts in Indonesia, a meeting in The Netherlands between the Cascading Semarang team and the University of Diponegoro (UNDIP), 
and three discussions with community leaders and villagers in Semarang. In total, 23 in-depth semi-structured interviews were conducted with participants and local, national, and international partners of the WaL program, the WaL program team, members of the multidisciplinary design teams, local policy officials, local academics, and local NGOs (see Appendix A Table A3). The interviewees were asked to explain and reflect on local flood problems, the ongoing flood resilience policies and initiatives in Semarang, and the implementation of the WaL program, that is, the institutional capacity building process for the development and implementation of the climate solutions.

Each interview was audio-recorded and fully transcribed. All research participants, organizers, and interviewees were informed of the purpose of this research and consented to the use of audio-recording and the interpretation of the data for this research. With the help of a local research assistance team at UNDIP, some meetings and interviews were conducted in the local language, Bahasa Indonesia, and later translated into English. Key policy documents and reports were also used to analyze local institutional capacity building for Semarang's flood adaptation. In total, 16 documents were used for this research, including program documents, seminar materials, and relevant resilience policy documents of the city of Semarang, such as its resilience strategy and the governmental spatial mid-term plan of the city of Semarang (see Appendix A Table A1).

Our analysis consisted of three main steps. The first step entailed exploring the local context, including the flood risks, and past and ongoing flood adaptation initiatives and programs in Semarang. In this step, we encapsulated the city's experience in international flood resilience programs, such as the ACCCRN and the 100RC program. The second step was the explorative analysis of the process of the WaL program. In this step, we identified the key actors involved, the program background, activities, and challenges. The third step was to investigate how the WaL program attempted to build on the institutional capitals described in Section 2. Code networks were developed for analyzing each type of capital—intellectual, social, and political capital—based on the analytical framework in Table 1. The documents and transcripts from the interviews, meetings, and discussions were thus deductively coded, using the computer program Atlas.ti (version 8).

\section{The Water as Leverage Program in Semarang: A Collaborative and Design Process for Local Institutional Capacity Building}

The WaL program is built on the idea that the program can constitute an "enabling environment" for multidisciplinary design teams to identify local challenges and co-design resilience solutions with local stakeholders. This is referred to as a "soft space" to design, develop, and implement climate solutions for local partners and stakeholders. Our analysis revealed three main processes that occurred within this soft space and can be seen as geared towards building different elements of institutional capital: (i) research and analysis of the local context (design-based research), (ii) co-creation and collaboration for design strategic climate solutions, and (iii) proposal development for finance and implementation. In Table 2, we outline some key activities that the WaL program has undertaken in relation to the build-up of intellectual capital, social capital, and political capital. We then present a more detailed analysis of how these key activities were perceived and translated into institutional capacity building in practice at the city level in Semarang. 
Table 2. Overview of key Water as Leverage (WaL) activities for local institutional capacity in Semarang, Indonesia.

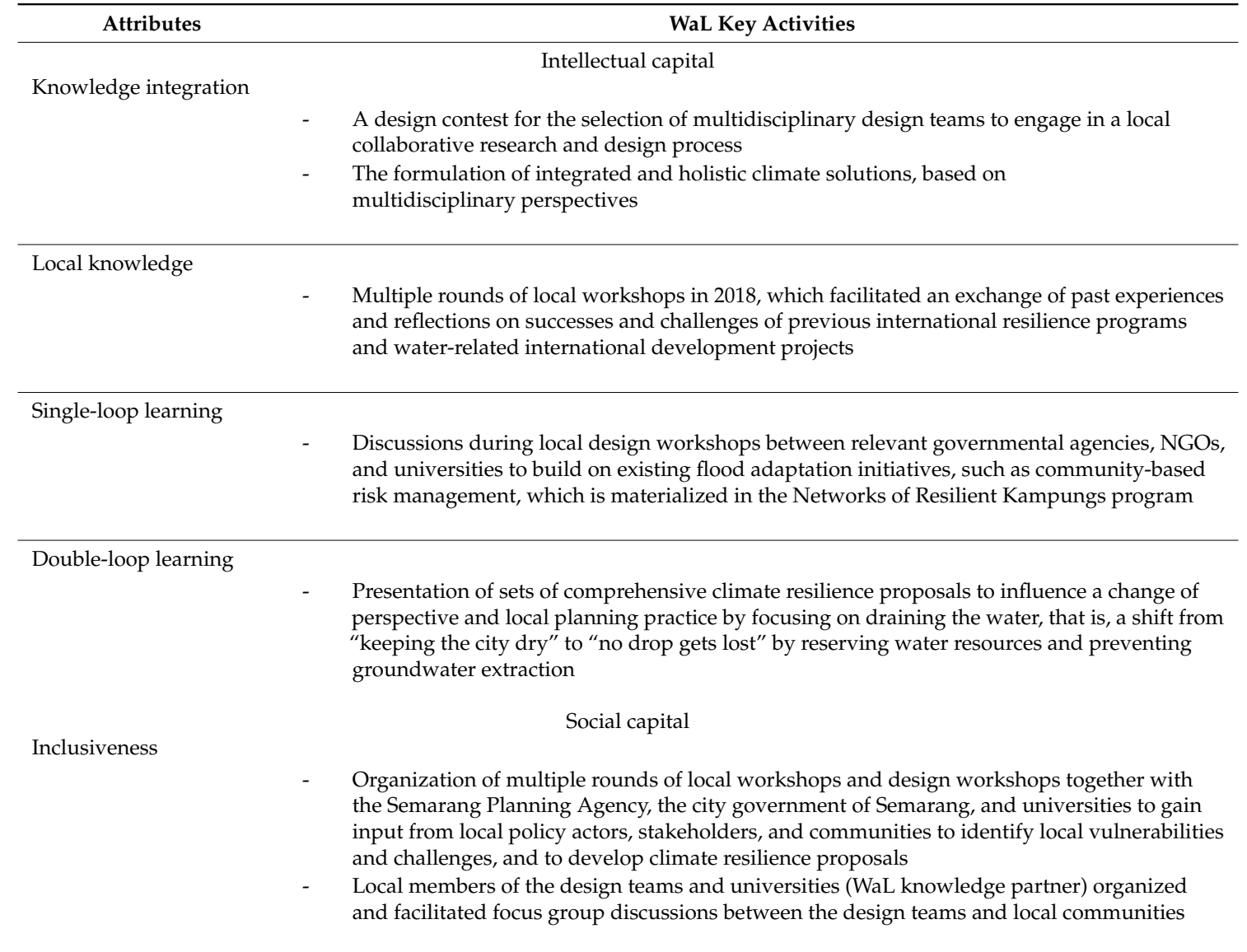

Shared values

- The selection criteria during the design contest, and the call for action, specify the emphasis on the holistic and social dimensions in the design of the proposals

- Illustration and communication of shared values on the holistic and social dimensions to government agencies and local stakeholders in the local workshops and design workshops

Network integration

Local ownership
- The organization of multiple rounds of local workshops and design workshops was in collaboration with governmental agencies and NGOs, such as Partnership for Resilience (a network of national and local NGOs collaborating on mainstreaming resilience policy), to support the design process

\section{Political capital}

- The coordination with the Semarang Planning Agency, the City Government of Semarang, and the city's resilience team for shared responsibilities in the local set-up and arrangement of the WaL activities in Semarang

- Communication with local policy officials for translation of the resilience concept in the city's government planning inspired by the conceptual design of the strategic climate resilience proposals

- The organization of sessions on climate financing such as the Regional Workshop in Singapore 2019, where the design teams could present their proposed climate resilience proposals and to discuss the financial project feasibility and implementation with financial institutions and international development partners

- The organization of sessions during local consultation workshops between the design teams, local partners and international financial institutions 
Table 2. Cont.

\begin{tabular}{ll}
\hline \multicolumn{1}{c}{ Attributes } & \multicolumn{1}{c}{ WaL Key Activities } \\
\hline Policy alignment & $\begin{array}{l}\text { The organization of interactions between the program and the Delegated Representative Water } \\
\text { Netherlands-Indonesia responsible so as to embed the WaL program in the memorandum of } \\
\text { understanding (MOU) bilateral water cooperation between The Netherlands and Indonesia } \\
\text { Establishment of a local WaL taskforce by the local program partners and local members of } \\
\text { the design teams for the coordination and communication about the proposed strategic climate } \\
\text { resilience proposals at the regional and national government }\end{array}$ \\
\hline Building narratives & $\begin{array}{l}\text { Development and presentation of a narrative for changing the city's flood risk management } \\
\text { and water management to create a shared vision on integrating spatial flood adaptation }\end{array}$ \\
\hline Change-agents & $\begin{array}{l}\text { Partnership with Semarang city's resilience team, which includes a network of the city's } \\
\text { governmental agencies such as the Semarang Planning Agency, local NGOs, and universities } \\
\text { for the set-up, initiation, and implementation of the WaL program }\end{array}$ \\
\hline
\end{tabular}

\subsection{Intellectual Capital}

The WaL program created opportunities for the involved multidisciplinary design teams to co-create water and climate solutions with local stakeholders in Semarang [48]. With respect to knowledge integration, the program launched a "Call for Action" for designers around the world to participate in a climate resilience design competition. The selected multidisciplinary design teams in Semarang, One Semarang and Cascading Semarang, included team members from a wide range of fields such as engineering, spatial design, urban planning, urban design, hydrology, and ecology [49]. The design teams were tasked with conducting design-based research, for which each team had to produce an in-depth research and analysis report in which they outlined interconnected environmental and urban risks, connected different flood risk management initiatives, and identified potential flood and climate resilience solutions for Semarang [50,51]. Both teams conducted the research and analysis to identify existing water and climate challenges and to explore potential holistic and integrated water and climate solutions for the city $[50,51]$. As a team member from One Semarang explained: "If all of the five proposals were implemented simultaneously, I think the impact on the city would be good in the sense that it's comprehensive and holistic." Initially, the two design teams worked separately on the design-based research and each performed their community engagement and focus-group discussions. However, over time, the two teams decided that it worked best to integrate their proposed resilience solutions and collaborations with local stakeholders. In the end, the two teams also jointly presented their city's flood and climate solutions. The design teams thus combined their solutions into six strategic water climate resilience proposals, which were presented as a coherent programmatic approach for improving Semarang's flood and climate resilience [49]. This integrated approach and the related six strategic proposals are outlined in Table 2, and present a combination of spatial adaptation measures, ecological and nature-based solutions, canal revitalization, and community flood preparedness.

With regard to local knowledge, the program organized several rounds of discussions during a local workshop in 2018. These discussions were meant to integrate Semarang's experience of previous resilience programs (such as ACCCRN and the 100RC program) with Water as Leverage. Program documents also emphasized the need for the integration of a broad range of knowledge, expertise, and the consideration of local insights, perspectives, and experience in order to deliver climate resilience proposals (see Table 3). However, at the same time, the program was perhaps too instrumental in its approach to doing so. Local stakeholders, such as the Partnership for Resilience (PFR), NGOs working on climate change and ecosystem management, and restoration programs that are supported by the Dutch Ministry of Foreign Affairs, felt there was still room to strengthen the integration of local 
insights especially regarding the inclusion of context-specific knowledge of local NGOs into the design of the resilience solutions. As the resources mobilization director of the Indonesia Science fund, who coordinated WaL activities with the local government, argued:

From my observation, I guess this involvement of this PFR (Partnership for Resilience) is not as much as it should be, but again I understand. Because initially the focus was mostly on the technical aspects and only thereafter on the design perspective.

The co-creation of strategic climate solutions has also stimulated both single-loop and double-loop learning processes among local partners and stakeholders. In relation to single-loop learning, the formulation of the six strategic climate resilience proposals was built from existing initiatives and ongoing projects, such as community-based risk management, with an attempt to improve, modify, and integrate these with other flood adaptation solutions. A local team member from One Semarang mentioned a particular initiative from the proposals:

One of our concepts is 'Networks of Resilient Kampungs' that is working for the community on the ground. It involves the modification of existing initiatives [the village level Disaster Preparedness Group (KSB)]. I mean it is good to work with them to learn from previous experiences and what can be modified and improved.

With regard to double-loop learning, the designed climate resilience solutions required the city's water planning and flood risk management approach to change focus from mainly "keeping the city dry" to "tapping into the water abundance and its possibilities" [49]. Against this backdrop, the Cascading Semarang team proposed effective storing and utilizing water resources to prevent groundwater usage in order to reduce urban flooding risks from land-subsidence. The corresponding strategic climate resilience proposals combine different flood adaptation measures to also instigate policy change in Semarang's planning and water management agencies. Learning and exchanging ideas on flood adaptation solutions were central in this learning process [50]. As Semarang's chief resilience technical coordinator of the city's resilience team stated: "We cannot rely on the government budget to solve all the water problems. From Water as Leverage, we learned how to innovate by expanding our work with international partners and international donors." In this context, Semarang's chief resilience officer, also part of the city's resilience team, referred to the "Feeding the industry" concept:

We learned a lot from the Water as Leverage process on how to retain the water. The other [strategic climate resilience proposal] concept was 'Feeding industries'. They [the design teams] have that concept to make the water resource allocation to industries. Just like that, we can learn from international experts.

The challenge now is to keep the continuation of research and analysis for the design of climate solutions in the local planning process.

Table 3. An overview of the WaL multidisciplinary design teams and the proposed strategic climate solutions for Semarang.

\begin{tabular}{|c|c|c|}
\hline Teams & Design Consortium Members & Strategic Climate Resilience Proposals \\
\hline One Resilient Semarang & $\begin{array}{l}\text { One Architecture \& Urbanism, Deltares, } \\
\text { Wetlands International, Kota Kita, } \\
\text { Sherwood Design Engineers, Hysteria } \\
\text { Grobak, Iqbal Reza, UNDIP }\end{array}$ & $\begin{array}{l}\text { 1. Water-Neutral industry (Demand) } \\
\text { 2. Networks of resilient kampungs } \\
\text { 3. Integrated protective coastal zone }\end{array}$ \\
\hline Cascading Semarang & $\begin{array}{l}\text { MLA+, Deltares, Fabrications, PT } \\
\text { Witteveen+Bos Indonesia, UNDIP, } \\
\text { UNISSULA, IDN Livable Cities }\end{array}$ & $\begin{array}{l}\text { 4. Feeding the industry (Supply) } \\
\text { 5. Spongy Mountain Terraces } \\
\text { 6. Rechanneling the city }\end{array}$ \\
\hline
\end{tabular}




\subsection{Social Capital}

To enable the co-creation of climate solutions, the program organized several local workshops and design workshops in Semarang [48]. In parallel, the design teams also conducted smaller stakeholder consultation activities, such as focus-group discussions and informal meetings with local communities. These activities are not only related to building intellectual capital, as discussed above, but also to building social capital at the local level. In relation to inclusiveness, the WaL local workshops and design workshops were organized to ensure that the design teams engaged with local stakeholders and partners at the city level for thinking along with the key challenges and priorities in the design process (see Figure 2). As a team member from One Semarang stated: "The process is trying to get everyone aligned with the same vision .... It just needs some effort to organize this process [of local engagement and collaboration] on the ground [bottom-up process]". However, there are some challenges in the inclusive collaboration process during the design of the adaptation strategies. For instance, a local team member who supported the community engagement of Cascading Semarang argued that local communities were more than interested in the concrete outcomes of projects but at the same time were less willing to engage or give input in the conceptual design process. The design teams experienced that the community members, who participated in the focus-group discussions, were reluctant to participate in the process since they were uncertain whether and how the project would be implemented. In addition, it was perceived as more challenging for local NGOs with limited resources to invest in the design contest. A local knowledge partner asserted that the program could have involved more local NGOs in the process: "They (the WaL program) needed to invite a wider range of participants, not only from the government but also from local NGOs. Semarang has a lot of NGOs and environmental NGOs. They have a lot of experience". The involvement of more local NGOs could have been rather valuable for inclusive collaboration and the embeddedness of the program in the local context.

With regard to shared values, the WaL program promoted holistic flood adaptation measures and social outcomes for the design and implementation of the climate resilience program. The program emphasized the holistic and social dimensions in the "Water as Leverage Guidelines" for the selection and evaluation of the proposals from the design teams. A team member from "Cascading Semarang" stressed the social components in the proposed solutions as follows: "We took these by heart and I think that's why we now have the [strategic climate resilience proposals]". The shared values are also illustrated in the design of the strategic climate resilience solutions and the communication with the local governmental agencies and NGOs during the local workshops.

In relation to network integration, the WaL program connected the multidisciplinary design teams with a network of NGOs such as Partnership for Resilience (PFR). In this context, a coordinator of PFR in Indonesia said: "We are connected to the Global Team in The Netherlands and we agreed to be a knowledge partner in the Water as Leverage [program]". Accordingly, representatives from the PFR participated in the local workshops and design workshops to give their input to the design teams especially regarding the alignment of the design of the solutions with existing water and flood resilience programs. The city (city government, city's resilience team, and local NGOs) itself was also open to collaboration with new partners from other cities or countries. As a local knowledge partner from Bintari Foundation (the Indonesia Association for Sustainable Development), a Semarang-based NGO, said: "Semarang is famous. I heard that the innovation of Semarang is [that the city is] open and open-minded and that they (the local government and NGOs) are also very open for collaboration". Based on their experience with international collaborations for flood and climate resilience, Semarang thus built extensive social capital to organize knowledge exchange and for international collaboration. The program was able to capitalize and further contribute to this capital by connecting local stakeholders with several international experts such as urban designers and landscape architects. However, the limited timeframe of the program constrained the community engagement process and in-depth consultation with local NGOs. The limited presence of the Semarang-based NGOs 
and the fact that the members of the teams were not based in the city were perceived as challenges to the local engagement process.

\subsection{Political Capital}

The building of political capital at the local level is important for the WaL program and for the design teams to bring the strategic climate resilience proposals to implementation. This involves communication and coordination at the local, national, and international levels. The co-creation of the strategic climate resilience proposals and engagement with key local government agencies promoted local ownership of the solutions. The initial set-up of the WaL program and the arrangement of its activities were executed by the close coordination between the RVO, the Semarang Planning Agency, and local partners, especially the city's resilience team. The co-creation of climate solutions promoted a local translation of the resilience concept and integrated resilience design into the city's planning process. As the research and development department head of Semarang's Planning Agency explained: "[Firstly,] we need to interpret the [resilience] concept and then we discuss. This is what we need to discuss and revise this part and then so on. This is a two-way [communication] process".

In relation to resource mobilization, the WaL program involved international financial organizations, such as the Asian Development Bank (ADB) and the World Bank, in the initial set-up of the program, the local workshop (during 2018-2019), regional workshops and the Singapore workshop (in 2019) to develop the conceptual design for financing and implementation. As a local knowledge partner of the WaL program stated:

The purpose [the meetings with the international financial institutions] is to approach and get input from the World Bank and the Asian Development Bank and others.... This is to make a proposal really bankable and submittable to financial institutions. There are a good chance and sufficient support to ensure that we can convince these financial institutions to finance this project.

Although the program was designed to involve the financial institutions at an early stage and during the regional workshops, the Semarang chief resilience technical coordinator of the city's resilience team indicated that the active involvement of international financial organizations in the design process and proposal development was limited. Nevertheless, at the time of writing, there are possibilities that the proposals may receive funding from Dutch government programs, such as Develop2Build, the World Bank program and the National Urban Development Project [52].

Regarding policy alignment, the WaL program utilized the bilateral agreement on water cooperation between The Netherlands and Indonesia, namely the "Memorandum of understanding (MOU) Water Indonesia-The Netherlands." As the Dutch government representative for the bilateral water cooperation stated at the beginning of the program: "Let's try to bring Water as Leverage under the MOU because only then I can coordinate properly. In the meantime, all the (existing) projects that are in Semarang or around Semarang have some overlap or are complementary". The knowledge partner from the Indonesia Science fund mentioned how the program organized workshops with governmental agencies that looked at ways to embed the strategic proposals in the policy plans: "They have been [trying to] tied up with the program that's already designed, or that's already decided, that's already been planned before. So, we have to make sure that this is not just another burden for the government". A team member from One Semarang commented on the potential alignment of a strategic program with the city plan by stating:

I think we are working on it in terms of, let's say, for the Resilient Kampungs, we are trying to engage them. The city government, BAPPEDA, says that they are and that they can commit. They are interested in taking that proposal in the city government program.

To support the continuation of the WaL activities and stimulate the proposal development process, the city's resilience team and local members of the design team formed the Water as Leverage Taskforce, which was responsible for policy alignment and maintaining relationships with the regional 
and national government. As the chief resilience technical coordinator explained: "The role of this taskforce is to establish connections with the provincial and national government. We should make an integrated claim and promote the Water as Leverage strategies there very well". However, despite these efforts, policy alignment at the regional and national levels was considered the main challenge confronted by the teams to move forward to the implementation process. The implementation of the strategic climate resilience proposals, such as the Integrated Protective Coastal Zone program, required coordination across governmental agencies at the local and regional levels. As a knowledge partner from the Initiative for Urban Climate Change and Environment (IUCCE) stated:

It is important (to) work closely with the provincial and national level government because some areas, rivers, and solutions [within the strategic climate resilience proposals] do not fall under the authority of the city but under the authority of the national and provincial governments.

The six proposed strategic climate resilience proposals were supported by the Semarang city government. During a local workshop, namely the International Seminar Water as Leverage Semarang, the MOU to put forward these proposals was signed by the mayor of Semarang, the Dutch water envoy and the Dutch ambassador to Indonesia [49]. The interviewees also commented that the WaL program stimulated the involvement of the design team members in giving input to the development of Semarang's upcoming spatial mid-term plan. However, the challenge is that the potential funding from international financial organizations requires the approval from and should be mandated by the national government. As a team member of the One Semarang team stated:

They [international financial organizations] always have to have the national government involved. Deciding on whether it was going to be a loan, grant, or extra budget from the national government, all those things have to be done through the national government.

The coordination with and approval from the national government was thus required for the mobilization of resources, especially funding in the proposal development and implementation. The presentation of the resilience proposals was accompanied by the following narrative of adaptation:

Semarang's future is secured through a combination of ecological restoration, economic growth, improved land governance and fostering of social capital within communities. This will be a paradigm shift that will break the vicious circle and propel Semarang into a resilient future.

(Water as Leverage, 2019b, p. 1)

The built narrative of adaptation consists of phrasings like "breaking the vicious circle", "taps into the abundance of water and possibilities" and "no-drop gets lost", which are used to characterize the urban flood and water solutions from the WaL program. It still requires considerable work to translate the overall narrative into the operational planning process and procedures of the city. However, this narrative is used as a communication tool and storyline for influencing policy change in the city's flood risk and water management to focus more on different types of spatial adaptation measures, such as Spongy Mountain Terrace.

Although it took more work than anticipated to embed the strategic proposals in the regional and national governments' plans for the implementation of the solutions, the role of the city's resilience team was important, as it turned out to be the change-agent for the city's resilience policy and collaboration with international partners. The city's resilience team consists of a network of local government agencies such as the Semarang Development Planning Agency, local NGOs such as the Initiative for Urban Climate Change and Environment (an NGO supporting the various flood adaptation initiatives), BINTARI (local environmental NGOs), and UNDIP. Their continual efforts have played a large part in evoking changes in the city's flood adaptation. The WaL knowledge partner from the Future Cities Laboratory Singapore (a project initiated by ETH Zurich) commented on the involvement of the University (UNDIP) as a change-agent stating, "I think the involvement 
of academics like the university is really good. They have students that enable the continuation. The involvement of students assists to help to communicate with the local people in Kampungs (community) and improve their capacity". Their support and close engagement with the design teams are essential for the implementation of proposals in the strategic climate resilience proposals, as their position further strengthens the bond between local institutions, local policy officials, and NGOs.

\section{Discussion}

\subsection{Institutional Strengths and Weaknesses}

The WaL program introduced a design and collaborative process, also referred to as "resilience by design", in the context of Semarang. Our results showed that this process stimulated the building of local institutional capacity, and thus strengthened the three elements of institutional capital: intellectual, social, and political capital. The program was able to integrate multidisciplinary knowledge, build coalitions and relations between the design teams and local stakeholders, and create shared ownership of the program's activities and ambitions with the city. However, the following institutional weaknesses could be identified. First, there is a lack of institutionalization of the resilience by design approach, which could lead to discontinuity of reflexive learning activities such as design-based research. Second, there is a lack of active engagement of city-based NGOs in the resilience by design process regarding their entering into the design contest. Third, there has been a lack of formal links with the national government at the initial stage of the program, and, consequently, there was little integration of the proposals in the existing institutional context. We have summarized these institutional strengths and weaknesses in Table 4.

Table 4. Institutional strengths and weaknesses of the WaL program in building local institutional capacity in Semarang.

\begin{tabular}{|c|c|c|}
\hline Elements & Institutional Strengths & Institutional Weaknesses \\
\hline Intellectual capital & $\begin{array}{l}\text { Integration of multidisciplinary knowledge } \\
\text { for co-creating flood adaptation solutions }\end{array}$ & $\begin{array}{l}\text { Lack of institutionalization of the resilience } \\
\text { by design approach and, therefore, the risk } \\
\text { of discontinuity }\end{array}$ \\
\hline Social capital & $\begin{array}{l}\text { Coalition and relation building between } \\
\text { the design teams and local stakeholders }\end{array}$ & $\begin{array}{l}\text { Lack of active engagement of city-based } \\
\text { NGOs in the resilience by design process }\end{array}$ \\
\hline Political capital & $\begin{array}{l}\text { Ownership and support of the local } \\
\text { government and the city's change-agents to } \\
\text { up take flood adaptation solutions }\end{array}$ & $\begin{array}{l}\text { Lack of formal links with the national } \\
\text { government and, consequently, little } \\
\text { integration of the proposals in the existing } \\
\text { institutional context }\end{array}$ \\
\hline
\end{tabular}

In the remainder of this section, we explain how these institutional strengths and weaknesses can be translated into three key challenges that the WaL program, and also other international resilience programs in Southeast Asia, encounter in the process of building local institutional capacities for long-term urban flood adaptation.

\subsection{Challenge 1: Sustaining Momentum for the Reflexive Learning Process}

The first challenge concerns the intellectual capital building and then, in particular, the reflexive learning process for exploring and experimenting with new flood adaptation solutions. The findings show that a strong element of the WaL program was the ability to build intellectual capital for the integration of knowledge, in terms of diverse insights and expertise. The consideration of local knowledge was also evident in the process of identifying social and climate vulnerabilities among local communities during the design-based research. Thus, an important strength of the program was the integration of knowledge to reframe flood and water problems and the way in which it succeeded in envisioning new climate solutions. Despite this strength, planning toward long-term flood adaptation requires capacity of the city to sustain and enhance momentum for the learning process $[33,53]$, that is, for the development of new strategies and solutions. For long-term urban flood adaptation, it remains 
unclear whether the local government in Semarang and other local actors will be able to organize a similar type of resilience by design process by themselves, if and when the program has ended. According to Liao [7] and Pahl-Wostl et al. [15], a continuous learning process, for instance, which informs to experimenting with new ideas and learning by doing, is essential for the policy change toward flood adaptation. Our results showed that the program still needs to transfer and embed WaL's design-based research and co-creation process at the city level.

\subsection{Challenge 2: Involving Local NGOs}

A second challenge relates to social capital building and in particular the inclusive engagement of local NGOs. There has proved to be a limited presence of Semarang-based NGOs in the WaL program. When we compare WaL to the previous international resilience programs in Semarang, such as ACCCRN and 100RC $[10,23,25]$, the major strength of the WaL program, through the design process, was its ability to bring various international and local spatial designers, academics, urban planners, social scientists, international and national NGOs, international financial institutions, and water experts into the local context. This process resulted in the materialization of the resilience concept into various design proposals. However, critical attention should be paid to opportunities of local NGOs, especially local NGOs with limited resources, to take part in the resilience by design process. The involvement of Semarang-based NGOs and the local representation in the design teams would be beneficial in bringing the design of flood adaptation solutions into a formal institutional context, especially to sustain the program's ambitions in the city and country. This process is essential for generating social capital to stimulate new planning practices that could enhance policy responses to climate stresses [14,38].

\subsection{Challenge 3: Establishing Policy Alignment and Formal Links with Decision Makers}

The third challenge relates to political capital building and the need for policy alignment in order to develop project proposals for implementation. Our results indicate that in Semarang, the national government was not involved at the essential early stage of the WaL program, such as during the design of the strategic climate resilience proposals. Formal coordination with the national government, which is necessary to ensure political buy-in of the design teams' proposals, did not occur at this early stage. This missing link with the national government hindered proposal development, financing and implementation, as the proposals required different sources of funding, national government budget, and international loans. This challenge in the development from conceptual design to financing and implementation was similarly evidenced in the Rebuild by Design program [46]. Rebuild by Design in the United States also experienced implementation barriers such as the limited timeframe of the program to engage and establish relations with official decision makers, the incompatibilities of designed solutions with existing plans and regulations, and the reliance on large investments from various external financial sources (i.e., private investment or international financial assistance) [46,47]. However, at the same, it is also important to consider that alignment in the top-down process right at the beginning could potentially limit the innovative process and proactive role of the local government.

\section{Conclusions}

This paper aimed to understand how international resilience programs, by promoting a resilience by design approach after the example of the Rebuild by Design program in the US, enabled the building of local institutional capacities for the development and implementation of flood adaptation strategies in Southeast Asian cities. To this end, we developed an institutional capacity-building framework, focusing on three elements of institutional capital: intellectual, social, and political capital. This framework proved to be a useful analytical lens to capture the complex process of building institutional capacities and to highlight the key activities in this context of international resilience programs.

This paper concludes that the WaL program introduced an innovative approach for relationship building and network integration between the multidisciplinary design teams (consisting of 
international experts and urban designers) and local stakeholders to co-create flood adaptation solutions. However, proposal development for financing and project implementation of these solutions remain challenging. We find that the program still needs to address the challenges related to the continuous and reflexive learning process, greater involvement of city-based NGOs, and policy alignment of the proposals including political support from national-level decision makers for further development of the conceptual design to project implementation.

Consequently, based on our analysis, there are three main recommendations for international resilience programs. These recommendations are focused on resilience programs in Southeast Asia but are also relevant for resilience programs in other parts of the world. First, this paper suggests such programs to begin with an in-depth analysis of the local institutional context in the early set-up and formulation of the program. The program should have insight into existing institutional challenges; thereby, it can identify key elements in institutional capital that are essential for the design, proposal development, and project implementation of flood adaptation solutions. In Semarang, for instance, local policy actors, knowledge institutions, and NGOs had limited political capital for project financing and implementation; therefore, the city required approval and support from the national government. Second, international resilience programs need to create opportunities for local organizations and governmental agencies to be actively involved in the resilience by design process (e.g., design contest and design-based research). It is useful for such programs to have a local-based office and representation of the design teams on the ground. Strong local ownership among stakeholders and involvement of local official decision makers throughout the process are crucial for the translation of innovative concepts into practice. Third and last, the consideration of existing local knowledge, culture, and experience is important to build local coalitions, create shared aspirations, and engage with and empower local communities. International resilience programs therefore should be built on and integrated with existing knowledge, social coalitions, and ambitions of the city's resilience front-runners. For this reason, such programs should be tailor-made to local conditions in order to capitalize on existing resources, knowledge, and experience in the city.

This research showed that the resilience by design process, which was developed by the WaL program, provided opportunities for local stakeholders to strengthen various aspects of their institutional capacities. Research about resilience planning processes and international resilience programs should thus not be limited to the exploration and assessment of the outcome of novel and integrated programs. This study showed that it is essential to understand whether and how such programs can contribute to the building of long-term local institutional capacities. Accordingly, this paper contributes to the development of an analytical framework for understanding how international resilience programs enable local institutional capacity building by strengthening intellectual, social, and political capital for the development and implementation of flood adaptation strategies. Our findings add to the knowledge and understanding regarding the institutional strengths and weaknesses of international resilience programs in planning processes for urban flood adaptation in a developing country context. Insights and recommendations from this paper may support governments and international institutions as well as local policy makers and planners to enhance local institutional capacities and address related institutional challenges to cope with flooding and climate impacts. These capacities are pivotal to the uptake of international lessons and examples and to drive local collective actions for urban flood adaptation.

Finally, for this paper, we used a single case study to examine the relationships between the resilience by design process and local institutional capacity building, and to discuss the key challenges in the context of a city in a developing country. Future research could consider using multiple case studies of international resilience programs to compare and explore the potential of or constraints in cross-border learning, collaboration, and international aid and development for inclusive urban flood resilience in different institutional contexts.

Author Contributions: The paper was written by N.L. based on the results obtained from his research, which was designed and conducted under the close supervision of M.v.d.B., J.A., and T.B.; editing and revising were done by 
N.L., M.v.d.B., T.B., J.A., and H.O.; access to the program information and activities and interviews was supported by H.O.; All authors have read and agreed to the published version of the manuscript.

Funding: This research received no external funding.

Acknowledgments: We would like to thank the Water as Leverage team, Sandra Schoof and Robert Proos, for supporting our data collection process. Special thanks to Wiwandari Handayani, Department of Urban and Regional Planning and the Research Group in Regional Development and Environmental Management at the Diponegoro University for their assistance and guidance during the fieldwork data collection. We also thank Laksmi T.D.J. Wisnu Wardani for providing us initial insights into the local research context.

Conflicts of Interest: The authors declare no conflict of interest.

\section{Appendix A}

Table A1. Documents and reports.

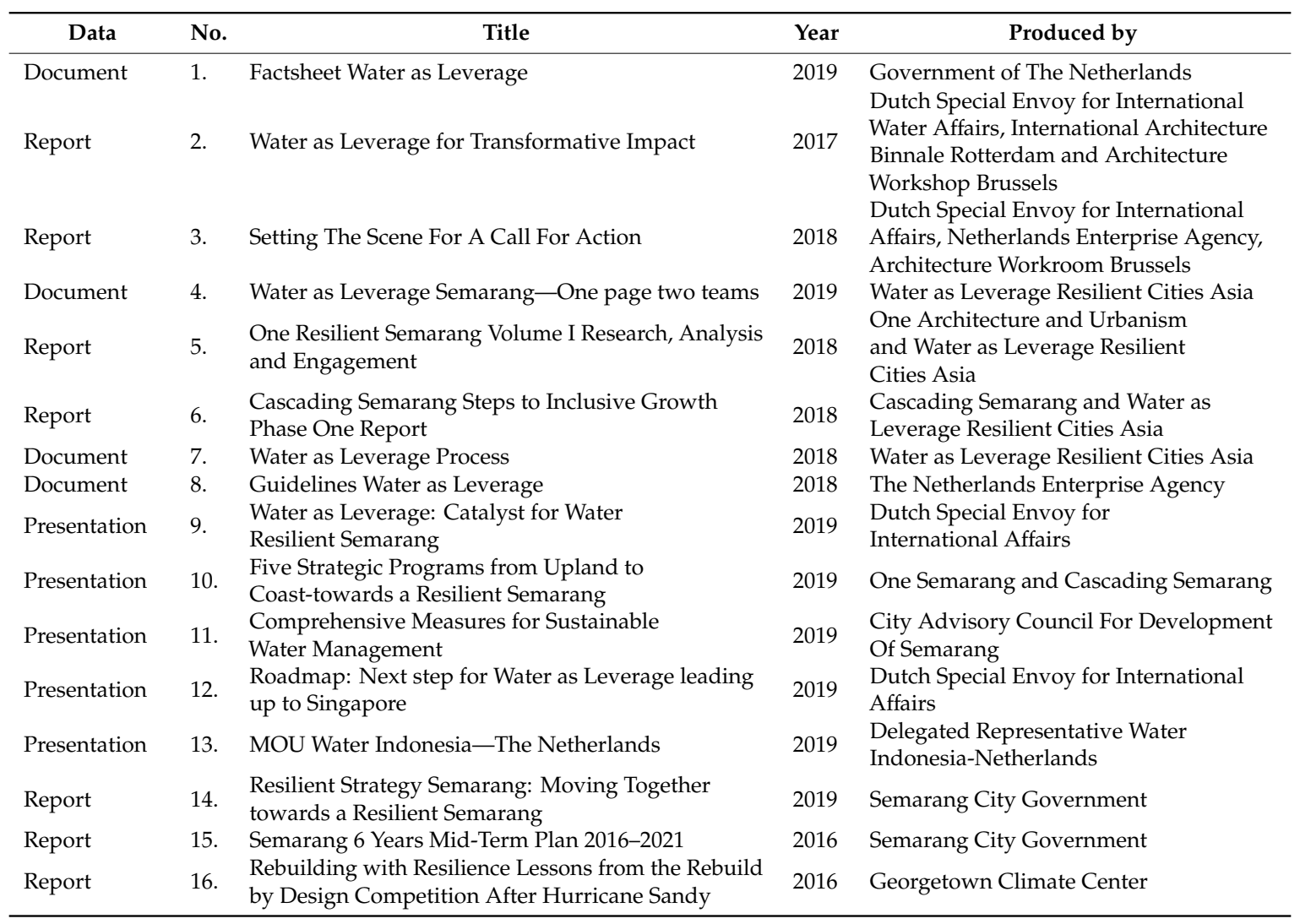

Table A2. Meetings and field visits for participatory observations.

\begin{tabular}{|c|c|c|c|c|}
\hline No. & Meetings & Location & Participants & Date \\
\hline 2. & $\begin{array}{l}\text { Site visits to survey locations for strategic } \\
\text { resilience proposals }\end{array}$ & Semarang, Indonesia & $\begin{array}{l}\text { Team members from } \\
\text { Cascading Semarang }\end{array}$ & 15 March 2019 \\
\hline 4. & $\begin{array}{l}\text { Filed visit and discussion with } \\
\text { community members from Pangong Lor }\end{array}$ & $\begin{array}{l}\text { Semarang, } \\
\text { Indonesia }\end{array}$ & $\begin{array}{l}\text { Research assistants from Diponegoro } \\
\text { University and community members }\end{array}$ & 28 March 2019 \\
\hline
\end{tabular}


Table A2. Cont.

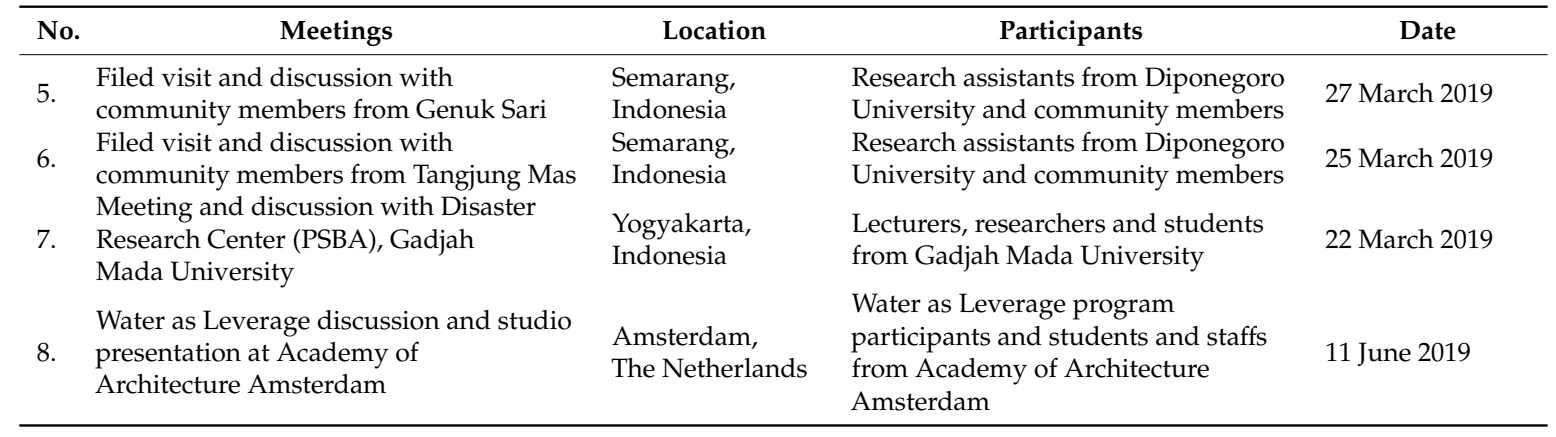

Table A3. List of interviews.

\begin{tabular}{|c|c|c|c|}
\hline No. & Title & Organization & Date of Interview \\
\hline 1. & $\begin{array}{l}\text { Technical advisor for Chief Resilience Officer } \\
\text { Semarang and Lecturer }\end{array}$ & $\begin{array}{l}\text { Semarang Resilience Office } \\
\text { and Diponegoro University }\end{array}$ & 21 March 2019 \\
\hline 2. & Urban Planner and member of One Resilient team & Kota Kita-Our City Foundation & 21 March 2019 \\
\hline 3. & $\begin{array}{l}\text { Program Director and member of One } \\
\text { Resilient team }\end{array}$ & Kota Kita-Our City Foundation & 5 April 2019 \\
\hline 4. & $\begin{array}{l}\text { Urban Strategic Planner and member of Cascading } \\
\text { Semarang team }\end{array}$ & IDN Livable Cities & 22 March 2019 \\
\hline 5. & $\begin{array}{l}\text { Urban Consultant and member of Cascading } \\
\text { Semarang team }\end{array}$ & IDN Livable Cities & 23 March 2019 \\
\hline 6. & $\begin{array}{l}\text { Process Manager and member of cascading } \\
\text { Semarang team }\end{array}$ & Witteveen Bos & 4 March 2019 \\
\hline 7. & $\begin{array}{l}\text { Climate and Resilience Advisor and knowledge } \\
\text { partner for Water as Leverage }\end{array}$ & IFRC Indonesia & 11 March 2019 \\
\hline 8. & $\begin{array}{l}\text { Governance Specialist and knowledge partner for } \\
\text { Water as Leverage }\end{array}$ & Mercy Corps Indonesia & 19 March 2019 \\
\hline 9. & $\begin{array}{l}\text { Independent Consultant and knowledge partner } \\
\text { for Water as Leverage }\end{array}$ & Mercy Corps Indonesia & 19 March 2019 \\
\hline 10. & $\begin{array}{l}\text { Green Policy Manager and knowledge partner for } \\
\text { Water as Leverage }\end{array}$ & WWF-Indonesia & 21 March 2019 \\
\hline 11. & Lead Water Program for Greater Mekong region & WWF Greater Mekong & 21 March 2019 \\
\hline 12. & $\begin{array}{l}\text { Senior Project Manager and member of One } \\
\text { Resilient team and Cascading Semarang Team }\end{array}$ & Deltares Indonesia & 5 April 2019 \\
\hline 13. & $\begin{array}{l}\text { Program and Alliance Lead and knowledge } \\
\text { partner for Water as Leverage }\end{array}$ & Care International Indonesia & 5 April 2019 \\
\hline 14. & $\begin{array}{l}\text { Resource Mobilization Director and program } \\
\text { partner for Water as Leverage }\end{array}$ & Indonesia Science Fund & 27 March 2019 \\
\hline 15. & $\begin{array}{l}\text { Project Consultant and knowledge partner for } \\
\text { Water as Leverage }\end{array}$ & Future Cities Laboratory Singapore & 21 March 2019 \\
\hline 16. & $\begin{array}{l}\text { Delegated Representative Water } \\
\text { Netherlands-Indonesia }\end{array}$ & $\begin{array}{l}\text { Netherlands Enterprise Agency } \\
\text { and Office of Ministry of Public } \\
\text { Works Indonesia }\end{array}$ & 4 April 2019 \\
\hline 17. & $\begin{array}{l}\text { Program Manager and knowledge partner for } \\
\text { Water as Leverage }\end{array}$ & $\begin{array}{l}\text { Bintari Foundation一the Indonesia } \\
\text { Association for Sustainable Development }\end{array}$ & 2 April 2019 \\
\hline 18. & $\begin{array}{l}\text { Former Environmental Board and City Resilience } \\
\text { Team of Semarang }\end{array}$ & The Government of Semarang & March 262019 \\
\hline 19. & $\begin{array}{l}\text { Former Chief Resilience Officer and Public Relation } \\
\text { Manager at City Council Secretariat of Semarang }\end{array}$ & $\begin{array}{l}\text { Semarang Resilience Office } \\
\text { and the Government of Semarang }\end{array}$ & 20 March 2019 \\
\hline 20. & $\begin{array}{l}\text { Chief Resilience Officer and Head of Infrastructure } \\
\text { and Environment Research and Development }\end{array}$ & $\begin{array}{l}\text { Semarang Resilience Office } \\
\text { and Development Planning Agency } \\
\text { of Semarang }\end{array}$ & 30 March 2019 \\
\hline 21. & $\begin{array}{l}\text { Manager of Initiative for Urban Climate Change } \\
\text { and Environment (IUCCE), Communication } \\
\text { Manager of City Resilience Team and platform } \\
\text { partner of Water as Leverage }\end{array}$ & $\begin{array}{l}\text { Initiative for Urban Climate Change } \\
\text { and Environment (IUCCE) }\end{array}$ & 27 March 2019 \\
\hline 22. & $\begin{array}{l}\text { Independent Journalist and Member of Society of } \\
\text { Indonesian Environmental Journalists }\end{array}$ & $\begin{array}{l}\text { Society of Indonesian Environmental } \\
\text { Journalists }\end{array}$ & 19 March 2019 \\
\hline 23. & $\begin{array}{l}\text { Lecturer and member of Semarang's City } \\
\text { Resilience Office }\end{array}$ & Diponegoro University & 27 March 2019 \\
\hline
\end{tabular}




\section{References}

1. Pillai, P.; Philips, B.; Shyamsundar, P.; Ahmed, K.; Wang, L. Climate Risks and Adaptation in Asian Coastal Megacities; The World Bank: Washington, DC, USA, 2010.

2. PBL. Geography of Future Water Challenges; PBL Netherlands Environmental Agency: The Hague, The Netherlands, 2018.

3. Vinke, K.; Schellnhuber, H.J.; Coumou, D.; Geiger, T.; Glanemann, N.; Huber, V.; Knaus, M.; Kropp, J.; Kriewald, S.; Laplante, B. A Region at Risk: The Human Dimensions of Climate Change in Asia and the Pacific; Asian Development Bank: Manila, Philippines, 2017.

4. Lebel, L.; Manuta, J.; Garden, P. Institutional traps and vulnerability to changes in climate and flood regimes in Thailand. Reg. Environ. Chang. 2010, 11, 45-58. [CrossRef]

5. Gersonius, B.; van Buuren, A.; Zethof, M.; Kelder, E. Resilient flood risk strategies: Institutional preconditions for implementation. Ecol. Soc. 2016, 21. [CrossRef]

6. Hegger, D.L.T.; Driessen, P.P.J.; Wiering, M.; van Rijswick, H.F.M.W.; Kundzewicz, Z.W.; Matczak, P.; Crabbé, A.; Raadgever, G.T.; Bakker, M.H.N.; Priest, S.J.; et al. Toward more flood resilience: Is a diversification of flood risk management strategies the way forward? Ecol. Soc. 2016, 21. [CrossRef]

7. Liao, K.-H. A Theory on urban resilience to floods-A basis for alternative planning practices. Ecol. Soc. 2012, 17. [CrossRef]

8. Lu, P.; Stead, D. Understanding the notion of resilience in spatial planning: A case study of Rotterdam, The Netherlands. Cities 2013, 35, 200-212. [CrossRef]

9. Sörensen, J.; Persson, A.; Sternudd, C.; Aspegren, H.; Nilsson, J.; Nordström, J.; Jönsson, K.; Mottaghi, M.; Becker, P.; Pilesjö, P.; et al. Re-Thinking urban flood management-Time for a regime shift. Water 2016, 8332. [CrossRef]

10. Spaans, M.; Waterhout, B. Building up resilience in cities worldwide-Rotterdam as participant in the 100 resilient cities programme. Cities 2017, 61, 109-116. [CrossRef]

11. United Nations. Goal 11: Make Cities Inclusive, Safe, Resilient and Sustainable. Available online: https://www.un.org/sustainabledevelopment/cities/ (accessed on 15 September 2020).

12. Wesselink, A.; Warner, J.; Syed, M.A.; Chan, F.; Tran, D.D.; Huq, H.; Huthoff, F.; Le Thuy, F.; Le Thuy, N.; Pinter, N. Trends in flood risk management in deltas around the world: Are we going 'soft'. Int. J. Water Gov. 2015, 3, 25-46.

13. Restemeyer, B.; Woltjer, J.; van den Brink, M. A strategy-based framework for assessing the flood resilience of cities-A Hamburg case study. Plan. Theory Pract. 2015, 16, 45-62. [CrossRef]

14. Driessen, P.P.J.; Hegger, D.L.T.; Bakker, M.H.N.; van Rijswick, H.F.M.W.; Kundzewicz, Z.W. Toward more resilient flood risk governance. Ecol. Soc. 2016, 21. [CrossRef]

15. Pahl-Wostl, C.; Becker, G.; Knieper, C.; Sendzimir, J. How multilevel societal learning processes facilitate transformative change: A comparative case study analysis on flood management. Ecol. Soc. 2013, 18, 58. [CrossRef]

16. Brown, A.; Rogers, B.C.; Werbeloff, L. A framework to guide transitions to water sensitive cities. In Urban Sustainability Transitions; Springer: Berlin/Heidelberg, Germany, 2018; pp. 129-148.

17. Restemeyer, B.; van den Brink, M.; Woltjer, J. Resilience unpacked—Framing of 'uncertainty' and 'adaptability' in long-term flood risk management strategies for London and Rotterdam. Eur. Plan. Stud. 2018, 26, 1559-1579. [CrossRef]

18. Pahl-Wostl, C.; Arthington, A.; Bogardi, J.; Bunn, S.E.; Hoff, H.; Lebel, L.; Nikitina, E.; Palmer, M.; Poff, L.N.; Richards, K. Environmental flows and water governance: Managing sustainable water uses. Curr. Opin. Environ. Sustain. 2013, 5, 341-351. [CrossRef]

19. Saito, N. Mainstreaming climate change adaptation in least developed countries in South and Southeast Asia. Mitig Adapt. Strat Gl. 2012, 18, 825-849. [CrossRef]

20. Handayani, W.; Fisher, M.R.; Rudiarto, I.; Sih Setyono, J.; Foley, D. Operationalizing resilience: A content analysis of flood disaster planning in two coastal cities in Central Java, Indonesia. Int. J. Disaster Risk Reduct. 2019, 35. [CrossRef]

21. Lebel, L.; Anderies, J.M.; Campbell, B.; Folke, C.; Hatfield-Dodds, S.; Hughes, T.P.; Wilson, J. Governance and the capacity to manage resilience in regional social-ecological systems. Ecol. Soc. 2006, 11, 19. [CrossRef] 
22. Marks, D.; Elinoff, E. Splintering disaster: Relocating harm and remaking nature after the 2011 floods in Bangkok. Int. Dev. Plan. Rev. 2019, 42, 273-295. [CrossRef]

23. Kernaghan, S.; da Silva, J. Initiating and sustaining action: Experiences building resilience to climate change in Asian cities. Urban. Clim. 2014, 7, 47-63. [CrossRef]

24. Water as Leverage. Water as Leverage Resilient Cities Asia. Available online: https://waterasleverage.org/ (accessed on 10 December 2019).

25. Brown, A.; Dayal, A.; Del Rio, R.C. From practice to theory: Emerging lessons from Asia for building urban climate change resilience. Environ. Urban. 2012, 24, 531-556. [CrossRef]

26. Friend, R.; Jarvie, J.; Reed, S.O.; Sutarto, R.; Thinphanga, P.; Toan, V.C. Mainstreaming urban climate resilience into policy and planning; reflections from Asia. Urban. Clim. 2014, 7, 6-19. [CrossRef]

27. Reed, S.O.; Friend, R.; Jarvie, J.; Henceroth, J.; Thinphanga, P.; Singh, D.; Tran, P.; Sutarto, R. Resilience projects as experiments: Implementing climate change resilience in Asian cities. Clim. Dev. 2014, 7, 469-480. [CrossRef]

28. Cars, G.; Healey, P.; Madanipour, A.; De Magalhaes, C. Urban. Governance, Institutional Capacity and Social Milieux; Routledge: Abingdon, UK, 2017.

29. Healey, P. Building institutional capacity through collaborative approaches to urban planning. Environ. Plan. A 1998, 30, 1531-1546. [CrossRef]

30. Healey, P. Collaborative planning in perspective. Plan. Theory 2003, 2, 101-123. [CrossRef]

31. Scott, M.; White, I.; Kuhlicke, C.; Steinführer, A.; Sultana, P.; Thompson, P.; Minnery, J.; O’Neill, E.; Cooper, J.; Adamson, M.; et al. Living with flood risk/The more we know, the more we know we don't know: Reflections on a decade of planning, flood risk management and false precision/Searching for resilience or building social capacities for flood risks?/Participatory floodplain management: Lessons from Bangladesh/Planning and retrofitting for floods: Insights from Australia/Neighbourhood design considerations in flood risk management/Flood risk management-Challenges to the effective implementation of a paradigm shift. Plan. Theory Pract. 2013, 14, 103-140. [CrossRef]

32. Booher, D.E.; Innes, J.E. Network power in collaborative planning. J. Plan. Educ. Res. 2002, 21, 221-236. [CrossRef]

33. Pahl-Wostl, C.; Craps, M.; Dewulf, A.; Mostert, E.; Tabara, D.; Taillieu, T. Social learning and water resources management. Ecol. Soc. 2007, 12, 19. [CrossRef]

34. Dai, L.; van Rijswick, H.F.M.W.; Driessen, P.P.J.; Keessen, A.M. Governance of the sponge city programme in China with Wuhan as a case study. Int. J. Water Resour. Dev. 2017, 34, 578-596. [CrossRef]

35. Khakee, A. Assessing institutional capital building in a local agenda 21 process in go teborg. Plan. Theory Pract. 2010, 3, 53-68. [CrossRef]

36. Aldrich, D.P.; Meyer, M.A. Social capital and community resilience. Am. Behav. Sci. 2014, 59, $254-269$. [CrossRef]

37. Bergsma, E. Changed knowledge requirements for spatial flood governance. Ecol. Soc. 2016, 21. [CrossRef]

38. Pelling, M.; High, C. Understanding adaptation: What can social capital offer assessments of adaptive capacity? Glob. Environ. Chang. 2005, 15, 308-319. [CrossRef]

39. Gupta, J.; Termeer, C.; Klostermann, J.; Meijerink, S.; van den Brink, M.; Jong, P.; Nooteboom, S.; Bergsma, E. The adaptive capacity wheel: A method to assess the inherent characteristics of institutions to enable the adaptive capacity of society. Environ. Sci. Policy 2010, 13, 459-471. [CrossRef]

40. Folke, C.; Carpenter, S.R.; Walker, B.; Scheffer, M.; Chapin, T.; Rockstrom, J. Resilience thinking: Integrating resilience, adaptability and transformability. Ecol. Soc. 2010, 15, 9. [CrossRef]

41. Pahl-Wostl, C. A conceptual framework for analysing adaptive capacity and multi-level learning processes in resource governance regimes. Glob. Environ. Chang. 2009, 19, 354-365. [CrossRef]

42. Breukers, S.; Wolsink, M. Wind energy policies in The Netherlands: Institutional capacity-building for ecological modernisation. Environ. Politics 2007, 16, 92-112. [CrossRef]

43. Davoudi, S.; Shaw, K.; Haider, L.J.; Quinlan, A.E.; Peterson, G.D.; Wilkinson, C.; Fünfgeld, H.; McEvoy, D.; Porter, L.; Davoudi, S. Resilience: A bridging concept or a dead end? "Reframing" resilience: Challenges for planning theory and practice interacting traps: Resilience assessment of a pasture management system in northern Afghanistan urban resilience: What does it mean in planning practice? Resilience as a useful concept for climate change adaptation? The politics of resilience for planning: A cautionary note. Plan. Theory Pract. 2012, 13, 299-333. [CrossRef] 
44. Meijerink, S.; Huitema, D.J.E. Policy entrepreneurs and change strategies: Lessons from sixteen case studies of water transitions around the globe. Ecol. Soc. 2010, 15, 19. [CrossRef]

45. Allmendinger, P.; Haughton, G. Soft spaces, fuzzy boundaries, and metagovernance: The new spatial planning in the Thames gateway. Environ. Plan. A 2009, 41,617-633. [CrossRef]

46. Lochhead, H. Resilience by design: Can innovative processes deliver more? Procedia Eng. 2017, 180, 7-15. [CrossRef]

47. Šakić-Trogrlić, R.; Rijke, J.; Dolman, N.; Zevenbergen, C. Rebuild by design in Hoboken: A design competition as a means for achieving flood resilience of urban areas through the implementation of green infrastructure. Water 2018, 10, 553. [CrossRef]

48. Government of The Netherlands. Factsheet Water as Leverage; Ministry of Infrastructure and Water Management and Ministry of Foreign Affairs: The Hague, The Netherlands, 2019.

49. Water as Leverage (Ed.) Water as Leverage Team Approach [Factsheet]; Enterprise Agency: The Hague, The Netherlands, 2019.

50. Cascading Semarang. Cascading Semarang Steps to Inclusive Growth Phase One Report. 2018. Available online: https://www.mlaplus.com/wp-content/uploads/2019/12/Cascading-Semarang_Phase-Two_EnglishVersion_Report.pdf (accessed on 10 September 2020).

51. One Resilient Semarang. Research, Analysis and Engagement (Draft Report-For Workshop Purposes); One Resilient Semarang: Amsterdam, The Netherlands, 2018; Volume 1.

52. Government of The Netherlands. Water as Leverage for Resilient Cities Asia News Letter April 2020; RVO: The Hague, The Netherlands, 2020.

53. Pelling, M.; High, C.; Dearing, J.; Smith, D. Shadow spaces for social learning: A relational understanding of adaptive capacity to climate change within organisations. Environ. Plan. A Econ. Space 2008, 40,867-884. [CrossRef]

Publisher's Note: MDPI stays neutral with regard to jurisdictional claims in published maps and institutional affiliations.

(C) 2020 by the authors. Licensee MDPI, Basel, Switzerland. This article is an open access article distributed under the terms and conditions of the Creative Commons Attribution (CC BY) license (http://creativecommons.org/licenses/by/4.0/). 